\title{
A microsystem for the extraction and in-vitro translation of mouse embryo mRNA
}

\author{
P. R. Braude and H. R. B. Pelham* \\ Departments of Anatomy and ${ }^{*}$ Biochemistry, University of Cambridge, CB2 3DY, U.K.
}

\begin{abstract}
Summary. A micromethod is described for the extraction of mRNA from mouse ova and its translation in a message-dependent rabbit reticulocyte lysate system. Using this technique it has been possible, by SDS polyacrylamide gel fluorography, to visualize the products from the equivalent of 12.5 eggs.
\end{abstract}

\section{Introduction}

The development of the embryo early after fertilization may be regulated by immediate transcriptional activity, or may depend, wholly or in part, on mRNAs presynthesized and stored in the cytoplasm.

It has been clearly demonstrated in sea urchins and amphibians that early development and protein synthesis can proceed in the absence of a nucleus (Brachet, Ficq \& Tencer, 1963; Denny \& Tyler, 1964; Smith \& Ecker, 1965; Sargent \& Raff, 1976) or in the presence of transcriptional inhibitors (Gross \& Cousineau, 1964). Although transcriptional activity has been demonstrated in the early preimplantation stages of mammalian embryos (Knowland \& Graham, 1972; Schultz, Manes \& Hahn, 1973), protein synthesis and cleavage can occur in the presence of actinomycin D (Monesi \& Molinaro, 1970; Tasca \& Hillman, 1970) and $\alpha$-amanitin (Golbus, Calarco \& Epstein, 1973; Johnson, Handyside \& Braude, 1977; Levey, Troike \& Brinster, 1977; Braude, 1979), suggesting the presence of stable preformed templates.

During this period of nuclear independence, there are marked changes in the species of proteins normally synthesized by the embryo (Van Blerkom \& Brockway, 1975; Van Blerkom, Barton \& Johnson, 1976; Van Blerkom, 1977). To determine whether these new proteins are synthesized on recently transcribed templates, or whether they have been translated on stored presynthesized mRNA which has been post-transcriptionally activated, it is necessary to compare the actual protein synthetic activity of the embryo with that observed for its mRNA extracted and translated in vitro. To do this, an in-vitro system is required that will translate the small amounts of mRNA present in the limited number of cells available to the mammalian embryologist. Although there are a number of in-vitro translation systems available (Gurdon, Lane, Woodland \& Marbaix, 1971; Jacobs-Lorena \& Baglioni, 1972; Roberts \& Paterson, 1973), hitherto there has been no system with sufficient fidelity and efficiency and with low enough background to operate quantitatively and qualitatively on the micro-scale required.

To fulfil this need, we have modified the message-dependent reticulocyte lysate system, originally described by Pelham \& Jackson (1976), for use on small numbers of mammalian eggs and embryos.

\section{Materials and Methods}

\section{Collection of unfertilized eggs}

Unfertilized mouse eggs were obtained from female CFLP mice (Anglia Laboratory Animals) induced to superovulate with an i.p. injection of 5 i.u. PMSG (Folligon: Intervet, Bar 
Hill, Cambridge) followed $42-48 \mathrm{~h}$ later by 5 i.u. hCG (Chorulon: Intervet). The cumulus masses were released into phosphate-buffered medium $+10 \%$ fetal calf serum (PB 1: Whittingham \& Wales, 1969) 14-17 h after hCG. All the cumulus cells were removed by brief treatment in phosphate-buffered saline ( $\mathrm{pH} 7.3)$ containing hyaluronidase $(1 \mathrm{mg} / \mathrm{ml}$ : Koch Light Labs.) and $1 \%$ $(\mathrm{w} / \mathrm{v})$ polyvinylpyrrolidone, followed by washing the eggs through a number of changes of medium. The eggs finally were washed 4 times in $100 \mu$ drops of PB 1 containing bovine serum albumin $(4 \mathrm{mg} / \mathrm{ml})$ to remove any traces of the fetal calf serum. The eggs were then counted and transferred to a $1 \mathrm{ml}$ siliconized glass centrifuge tube in as small a drop of medium as possible. Ideally this was less than $5 \mu$ l, which usually entailed removing the excess medium by using a mouth pipette. The extraction was then immediately performed.

\section{RNA extraction}

A standard phenol extraction was used but on a scale commensurate with the small size of the sample. Redistilled phenol saturated with extraction buffer $(20 \mu \mathrm{l})$ was added to the sample tube followed by $20 \mu \mathrm{l}$ extraction buffer $(0.2 \mathrm{M}-\mathrm{HCl}, 10 \mathrm{~mm}$-EDTA, $20 \mathrm{~mm}$-TRIS, pH 7.4). Mouse liver tRNA $(2 \mu l, 1.625 \mathrm{mg} / \mathrm{ml})$ was also added to serve as carrier in the precipitation and as a precaution against nuclease degradation of the cellular RNA. The sample was then thoroughly vortexed and the emulsion transferred to a $50 \mu \mathrm{l}$ microhaematocrit capillary tube (Heraeus-Christ, Osterode am Harz, W. Germany) by capillary action. The capillary tube was then sealed at both ends with PVC putty (Critoseal: Sherwood Medical Industries, St Louis). In order to control for possible translational activity of the carrier tRNA an extraction was performed using the phenol, extraction buffer and the $2 \mu \mathrm{l}$ tRNA but no ova. After centrifugation (Microfuge Model HG 102, Heraeus-Christ) for about 1 min at 5000 r.p.m. to separate the mixture into two phases, the capillary tubes were scored with a glass cutter just above the interface, fractured, and the upper layers emptied into clean 1-ml centrifuge tubes. Then $60 \mu \mathrm{l}$ ethanol were added to each tube and the mixture was allowed to precipitate overnight at $-20^{\circ} \mathrm{C}$. The following morning the extracts were centrifuged at $-10^{\circ} \mathrm{C}$ for $30 \mathrm{~min}$ at $27000 \mathrm{~g}$ and the supernatants removed using a pulled Pasteur pipette. The pellets were then dissolved in $10 \mu \mathrm{l}$ $\left[{ }^{35} \mathrm{~S}\right]$ methionine (sp. act. $\sim 1000 \mathrm{Ci} / \mathrm{mmol}$ : Radiochemical Centre, Amersham) and immediately freeze dried.

\section{Preparation of the $m R N A$-dependent reticulocyte lysate}

The reticulocyte lysate was prepared according to the method of Pelham \& Jackson (1976), except that the dose of micrococcal nuclease used for the removal of the endogenous mRNA activity was doubled. Dithiothreitol $(2 \mathrm{~mm})$ was added to the lysate before storage in $50 \mu \mathrm{l}$ aliquots at $-70^{\circ} \mathrm{C}$.

\section{Translation procedure}

Immediately after freeze drying of the RNA, $15 \mu \mathrm{l}$ message-dependent lysate were added to each tube containing the dried pellets, thoroughly mixed, and incubated at $30^{\circ} \mathrm{C}$ for $1 \mathrm{~h}$. At the end of the incubation period a $2 \mu \mathrm{l}$ sample was taken for scintillation counting before $2 \mu \mathrm{l}$ of a solution containing $2 \mathrm{mg}$ pancreatic R Nase $/ \mathrm{ml}, 20 \mathrm{~mm}$-unlabelled methionine and $0.1 \mathrm{M}$-EDTA were added to each incubation mix, and incubation was continued for a further 10-20 min.

\section{Counting of the sample}

To assay protein synthesis quantitatively the $2 \mu \mathrm{l}$ aliquot was added to $250 \mu \mathrm{l}$ double-distilled water. To this was added $250 \mu \mathrm{l} \mathrm{N}-\mathrm{NaOH}$ containing $0.5 \mathrm{M}-\mathrm{H}_{2} \mathrm{O}_{2}$ (to bleach the sample) and 
$1 \mathrm{mg}$ unlabelled methionine/ml. After incubation at $30^{\circ} \mathrm{C}$ for about $15 \mathrm{~min}$ the protein was precipitated by the addition of $500 \mu \mathrm{l} 25 \%$ trichloroacetic acid. The precipitate was collected on glass-fibre discs (Whatman $\mathrm{GF} / \mathrm{C}$ ) and dried with a warm-air blower. The dried filters were counted using a toluene scintillant in a Packard model 3330 scintillation counter at an efficiency of about $70 \%$.

\section{Polyacrylamide gel electrophoresis}

Samples were analysed qualitatively in one dimension on SDS poly acrylamide slab gels (Van Blerkom \& Brockway, 1975) or in two dimensions (Handyside \& Johnson, 1978). For twodimensional analysis $10 \mu \mathrm{l}$ samples were mixed with an equal volume of double-strength lysis buffer (4.75 M-urea, 4\% (w/v) Nonidet P40 (B.D.H.), 4\% ampholines (3.2\% pH 5-7 and 0.8\% pH 3.5-10), 10\% mercaptoethanol) and more urea was added until the mixture was saturated. For one-dimensional analysis, 1 to $5 \mu \mathrm{l}$ aliquots were added to $20 \mu \mathrm{l}$ SDS sample buffer (O'Farrell, 1975). Radioactive proteins were visualized by fluorography (Laskey \& Mills, 1975) using preflashed Fuji Rx X-ray film (Bonner \& Laskey, 1974) and exposure for 2-6 weeks.

\section{Results}

\section{Quantitative aspects}

Using the system described, we have been able to translate successfully the RNA from small numbers of eggs and obtain 2- to 5-fold stimulation of methionine incorporation over the background (zero time values are not subtracted). The background incorporation was somewhat variable but ceased after 20 min whereas translation of added RNA continued for about $1 \mathrm{~h}$. Removal of the zona pellucida from the eggs before extraction did not significantly improve the yield of active mRNA (Text-fig. 1), but did make handling of the eggs much more difficult and

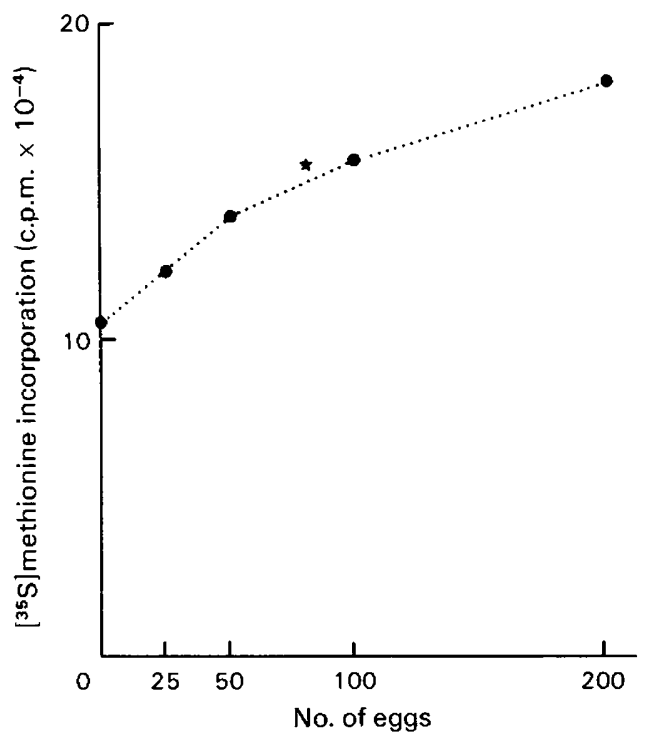

Text-fig. 1. Dose response to mRNA extracted from increasing numbers of eggs. RNA was extracted from $0,25,50,100$ and 200 unfertilized eggs with intact zonae pellucidae, and from 80 ova (*) which had their zonae removed by brief treatment in acid tyrode solution $+0.04 \%$ PVP (pH 2.5). The translations were performed for $1 \mathrm{~h}$ in $10 \mu \mathrm{l}$ reticulocyte lysate containing 2.7 $\mathrm{mCi}\left[{ }^{35} \mathrm{~S}\right]$ methionine (sp. act. $\left.830 \mathrm{Ci} / \mathrm{mmol}\right) / \mathrm{ml}$, followed by $1 \mathrm{~h}$ with another $10 \mu \mathrm{l}$ unlabelled lysate added to each incubation mix. The counts represent the incorporation into protein in the total incubation mixture $(20 \mu \mathrm{l})$ based on the acid-precipitable radioactivity of a $2 \mu \mathrm{l}$ sample. 
may increase the pre-extraction losses when large numbers of eggs are used. A dilution curve showed that the stimulation of translation was proportional to the amount of message added (Text-fig. 2), and there appeared to be no major inhibitors of translation present in the RNA preparation. Since the reticulocyte lysate itself contained some methionine, the level of incorporation depended not only on the specific activity of the added label, but also on its concentration. We have found that when very high levels of $\left[{ }^{35} \mathrm{~S}\right]$ methionine are used, there is some inhibition of protein synthesis due to the presence of oxidized mercaptoethanol in the radioactive methionine solution. This inhibition is avoided by the addition of $2 \mathrm{~mm}$-dithiothreitol to the translation system and, with this precaution, final $\left[{ }^{35} \mathrm{~S}\right]$ methionine concentrations of up to $10 \mathrm{mCi} / \mathrm{ml}$ could be used. We routinely add $4-5 \mathrm{mCi} / \mathrm{ml}$ and obtain $500-800$ c.p.m. incorporated per egg extracted.

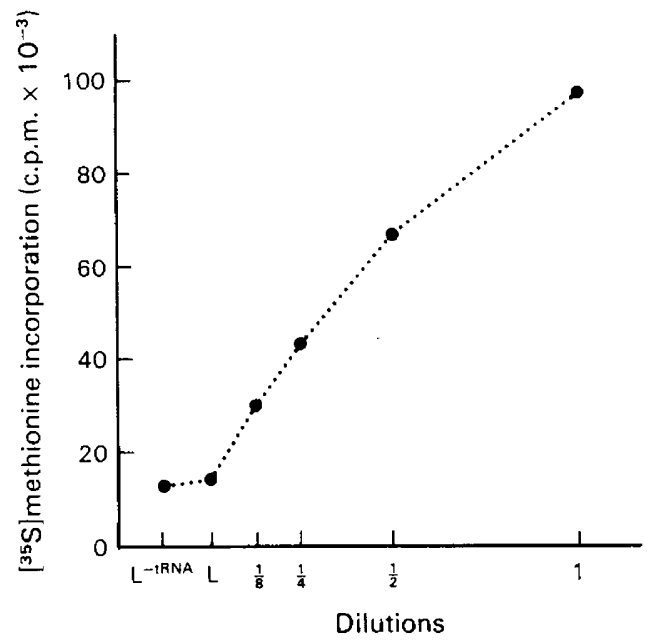

Text-fig. 2. Dose response to mRNA extracted from 400 ova. Freeze-dried RNA extracted from 400 unfertilized eggs $(\mathrm{hCG}+16 \mathrm{~h}$ ) was dissolved in $20 \mu \mathrm{l}$ labelled reticulocyte lysate containing $\left.1.33 \mathrm{mCi}{ }^{35} \mathrm{~S}\right]$ methionine (sp. act. $680 \mathrm{Ci} / \mathrm{mmol}$ )/ml, and $10 \mu \mathrm{l}$ of this mixture were serially diluted with $10 \mu \mathrm{l}$ labelled lysate; $10 \mu \mathrm{l}$ labelled lysate were also added to an empty incubation tube ( $\mathrm{L}^{-\mathrm{tRNA}}$ ) and to the products of an extraction containing carrier tRNA but no ova (L). The counts represent the incorporation into protein in the total incubation mix $(10 \mu l)$ based on the acid-precipitable radioactivity in a $2 \mu$ sample.

\section{Qualitative aspects}

Although the background 'incorporation' may be a significant fraction of the total, much of this appeared to be due to non-specific trapping of label. On SDS polyacrylamide slab gels the

\section{PLATE 1}

Fig. 1. Fluorograph of a $7-15 \%$ one-dimensional SDS polyacrylamide gel electrophoresis slab showing the $\left[{ }^{35} \mathrm{~S}\right]$ methionine-labelled products obtained from a $5 \mu \mathrm{l}$ sample of (a) intact unfertilized eggs labelled for $4 \mathrm{~h}$ in medium containing $\left[{ }^{35} \mathrm{~S}\right]$ methionine; (b) labelled reticulocyte lysate; (c) labelled reticulocyte lysate added to carrier tRNA extract; (d) in-vitro translation of 350 unfertilized eggs. The bands bracketed will normally not appear if the translation mixes are treated with RNase before electrophoresis.

Fig. 2. Fluorographs of a one-dimensional SDS polyacrylamide slab gel ( $7 \cdot 5-15 \%$ gradient), showing the $\left[{ }^{35} \mathrm{~S}\right]$ methionine products from a $5 \mu$ sample of the in-vitro translations shown in Text-fig. 2. All samples were treated with RNase before electrophoresis. Exposure to the preflashed X-ray film was for 5 days. 


\section{PLATE 1}

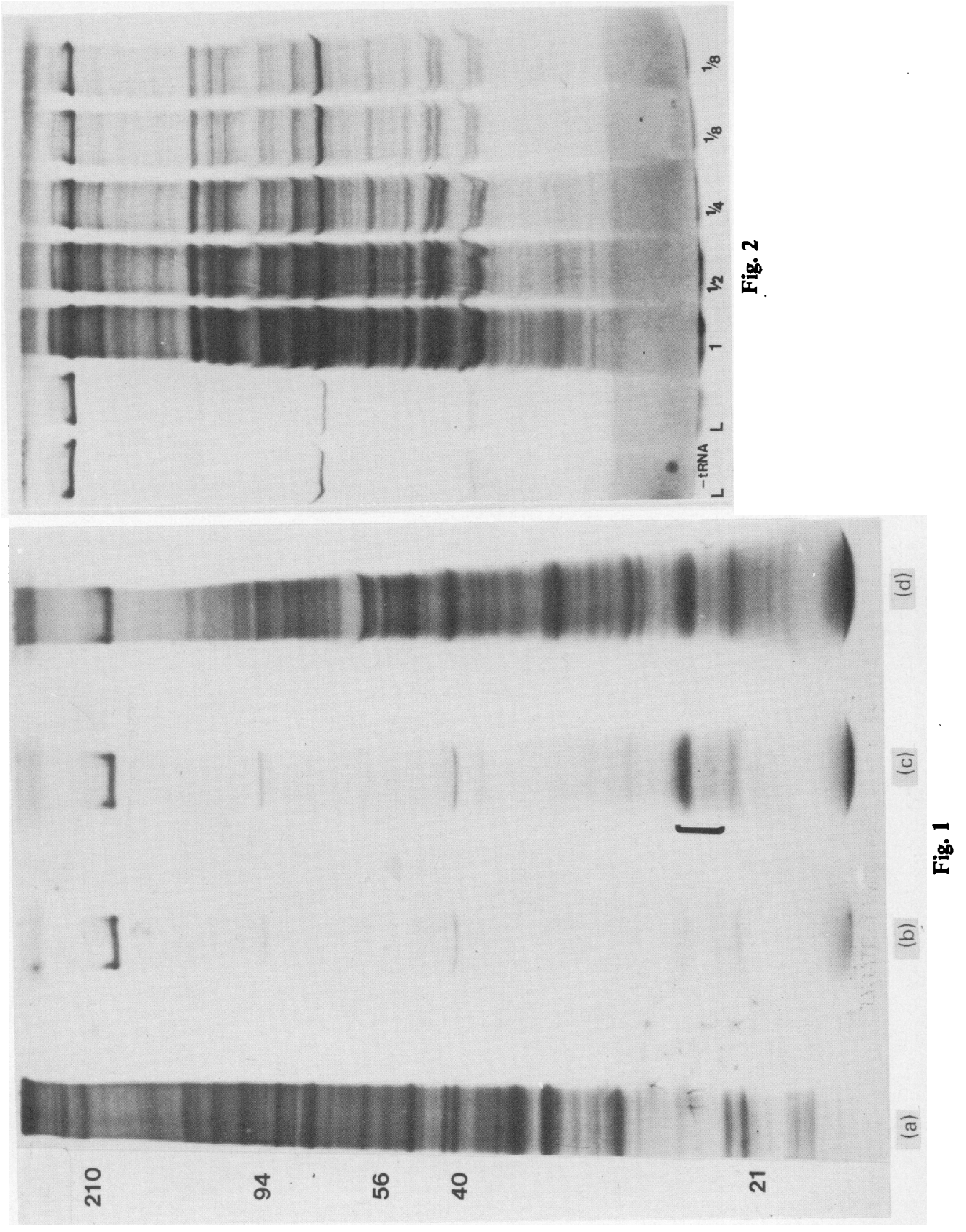

(Facing p. 156) 
PLATE 2

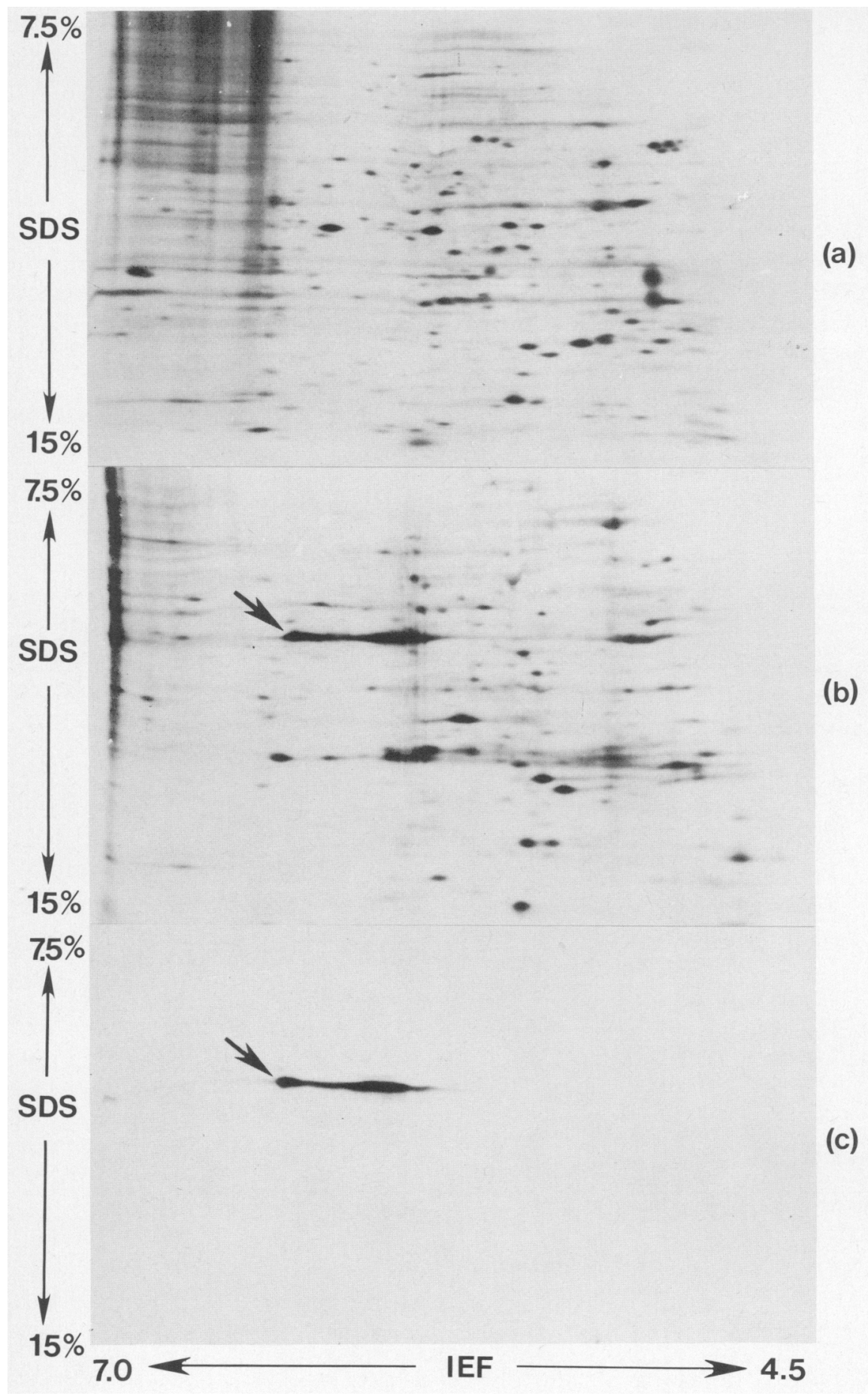


background appeared as a small number of discrete bands (Pl. 1, Fig. 1.). Some of these represented proteins labelled in a ribosome-independent reaction, and there was also some 'sticking' of $\left[{ }^{35} \mathrm{~S}\right]$ methionine to globin. A series of bands with apparent molecular weights of 20000 to 25000 have been identified as peptidyl tRNA formed by translation of globin mRNA fragments (unpublished observations). They can be removed by treatment of the incubation mix with ribonuclease before gel analysis. The large amount of protein in the reticulocyte lysate (haemoglobin was present at $50-60 \mathrm{mg} / \mathrm{ml}$ ) led to some distortion of the product pattern on onedimension SDS gels (Pl. 1, Fig. 1), and comparison of proteins made in vitro and in vivo was much easier when two-dimensional gels were used (Pl. 2, Fig. 3). On these, the in-vitro background was largely restricted to a single readily identifiable spot and streak. In general, most of the proteins made in intact eggs were also detectable amongst the cell-free translation products and vice versa (Pl. 2, Fig. 3). However, there were also some differences between the patterns.

Good one-dimensional gels were achieved from the products of translation of the equivalent of 12.5 eggs (Pl. 1, Fig. 2) after exposure for 5 days. Since the total RNA content of the unfertilized egg has been estimated at $0.554 \mathrm{ng}$ (Olds, Stern \& Biggers, 1973), and the percentage of mRNA is probably less than $10 \%$ of the total, then assuming $100 \%$ recovery of the RNA from the egg, we were visualizing the translation products of about $0.6 \mathrm{ng}$ mRNA. Longer exposure of one-dimensional fluorographs permitted detection of the products from the equivalent of 2.5 eggs (about $125 \mathrm{pg}$ mRNA based on the above calculations).

\section{Discussion}

We have presented here details of a new method, based on existing techniques, for the extraction and in-vitro translation of very small numbers of cells and minute amounts of mRNA. The use of capillary tubes enables a phenol extraction to be performed on a microscale with almost total recovery of the supernatant and little chance of contamination. The translation system has the great advantage over the other high sensitivity microsystem, that of the Xenopus oocyte (Gurdon et al., 1971), in that it has a qualitatively negligible endogenous synthesis in the absence of added mRNA and that it requires very little expertise and no specialized apparatus.

We have begun to use this system to study the molecular events involved in the development and differentiation of the early mammalian embryos with encouraging results, and suggest that this system can be applied in other types of study in which only limited amounts of material are available.

We wish to thank Dr Tim Hunt, Dr Martin Johnson and Dr Richard Jackson for their advice and encouragement, and Ginette Flach for her excellent technical assistance. This work was supported by grants from the Medical Research Council to Dr R. J. Jackson and Dr M. H. Johnson and from the Ford Foundation to Dr M. H. Johnson. H.R.B.P. was a recipient of an M.R.C. studentship.

\section{PLATE 2}

Fig. 3. Fluorographs of $\left[{ }^{35} \mathrm{~S}\right]$ methionine-labelled polypeptides synthesized by (a) 20 intact unfertilized ova labelled for $3 \mathrm{~h}$ in medium containing $\left.\mathrm{l}^{35} \mathrm{~S}\right]$ methionine; (b) the reticulocyte lysate in the presence of RNA extracted from 200 unfertilized eggs; (c) the reticulocyte lysate in the presence of extracted carrier tRNA. Horizontal separation was by isoelectric focusing between $\mathrm{pH} 7.0$ and 4.5 , and vertical separation was by $7.5-15 \%$ SDS gradient polyacrylamide gel electrophoresis. 


\section{References}

Bonner, W.M. \& Laskey, R.A. (1974) A film detection method for tritium-labelled proteins and nucleic acids in polyacrylamide gels. Eur. J. Biochem. 46, 83-88.

Brachet, J., Ficq, A. \& Tencer, R. (1963) Amino acid incorporation into proteins of nucleate and anucleate fragments of sea urchin eggs: Effect of parthenogenetic activation. Expl Cell Res. 32, 168-170.

Braude, P.R. (1979) Control of protein synthesis during blastocyst formation in the mouse. Devl Biol. (in press).

Denny, P.C. \& Tyler, A. (1964) Activation of protein biosynthesis in non-nucleate fragments of sea urchin eggs. Biochem. Biophys. Res. Commun. 14, 245-249.

Golbus, M.S., Calarco, P.G. \& Epstein, C.J. (1973) The effects of inhibitors of RNA synthesis ( $\alpha$-amanitin and actinomycin D) on preimplantation mouse embryogenesis. J. exp. Zool. 186, 207-216.

Gross, P.R. \& Cousineau, G.H. (1964) Macromolecule synthesis and the influence of actinomycin on early development. Expl Cell Res. 33, 368-395.

Gurdon, J.B., Lane, C.D., Woodland, H.R. \& Marbaix, G. (1971) Use of frog eggs and occytes for the study of messenger RNA and its translation in living cells. Nature, Lond. 233, 177-182.

Handyside, A.H. \& Johnson, M.H. (1978) Temporal and spatial patterns of synthesis of tissue-specific polypeptides in the pre-implantation mouse embryo. $J$. Embryol, exp. Morph. 44, 191-199.

Jacobs-Lorena, M. \& Baglioni, C. (1972) Characterization of a mouse ascites cell free system. Biochemistry, N.Y. 11, 4970-4973.

Johnson, M.H., Handyside, A.H. \& Braude, P.R. (1977) Control mechanisms in early mammalian development. In Development in Mammals, Vol. 2, pp. 6797. Ed. M. H. Johnson. Elsevier, Amsterdam.

Knowland, J. \& Graham, C. (1972) RNA synthesis at the two cell stage of mouse development. J. Embryol. exp. Morph. 27, 167-176.

Laskey, R.A. \& Mills, A.D. (1975) Quantitative film detection of ${ }^{3} \mathrm{H}$ and ${ }^{14} \mathrm{C}$ in polyacrylamide gels by fluorography. Eur. J. Biochem. 56, 335-341.

Levey, I.L., Troike, D.E. \& Brinster, R.L. (1977) Effects of $\alpha$-amanitin on the development of mouse ova in culture. J. Reprod. Fert. 50, 147-150.

Monesi, V. \& Molinaro, M. (1970) Macromolecular synthesis and effect of metabolic inhibitors during preimplantation development in the mouse. $A d v$. Biosci. 6, 101-120.

O'Farrell, P.H. (1975) High resolution two-dimensional electrophoresis of proteins. J. biol. Chem. 250, 40074020.

Olds, P.J., Stern, S. \& Biggers, J.D. (1973) Chemical estimates of the RNA and DNA contents of the early mouse embryo. J. exp. Zool. 186, 39-46.

Pelham, H.R.B. \& Jackson, R.J. (1976) An efficient mRNA-dependent translation system from reticulocyte lysates. Eur. J. Biochem. 67, 247-256.

Roberts, B.E. \& Paterson, B.M. (1973) Efficient translation of tobacco mosaic virus RNA and rabbit globin 9s RNA in a cell-free system from commercial wheat-germ. Proc. natn. Acad. Sci. U.S.A. 70, 23302334.

Sargent, T.D. \& Raff, R.A. (1976) Protein synthesis and messenger RNA stability in activated, enucleate sea urchin eggs are not affected by actinomycin D. Devl Biol. 48, 327-335.

Schultz, G.A., Manes, C. \& Hahn, W.E. (1973) Synthesis of RNA containing polyadenylic acid sequences in preimplantation rabbit embryos. Devl Biol. 30, $418-426$.

Smith, L.D. \& Ecker, R.E. (1965) Protein synthesis in enucleated eggs of Rana pipiens. Science, N.Y. 150, 777-779.

Tasca, R.J. \& Hillman, N. (1970) Effects of actinomycin $\mathrm{D}$ and cycloheximide on RNA and protein synthesis in cleavage stage mouse embryos. Nature, Lond. 225, 1022-1025.

Van Blerkom, J. (1977) Molecular approaches to the study of oocyte maturation and embryonic development. In Immunobiology of Gametes, pp. 184-206. Eds M. Edidin \& M. H. Johnson. Cambridge University Press.

Van Blerkom, J. \& Brockway, G.O. (1975) Qualitative patterns of protein synthesis in the preimplantation mouse embryo. Devl Biol. 44, 148-157.

Van Blerkom, J., Barton, S.C. \& Johnson, M.H. (1976) Molecular differentiation in the preimplantation mouse embryo. Nature, Lond. 259, 319-321.

Whittingham, D.G. \& Wales, R.G. (1969) Storage of two-cell mouse embryos in vitro. Aust. J. biol. Sci. 22, 1065-1068.

Received 21 August 1978 